\title{
The Story of Chinese Characters (0041-0050) when Translated on Korean Pronunciation
}

\author{
Hyeonhi Regina Park1, Kunjoo Daegon-Andrea Kim², Jiah Anna Kim³, Alain Hamon4, Rosa Kim5, Sohwa \\ Therese Kim${ }^{6}$, Sangdeog Augustin $\mathrm{Kim}^{7^{\star}}$ \\ 1Department of Elderly care and welfare, Joongbu University, Kumsan, Republic of Korea ROK \\ 2Department of History, Yonsei University, Seoul, ROK, \\ ${ }^{3}$ Department d'Expertise economique, Universite de Paris-Est Creteil, Paris, France \\ ${ }^{4} \mathrm{~L}$ 'Ecole Internationale Jean-Mermoz, Abidjan, Cote d'Ivoire, \\ ${ }^{5}$ Specialite d'Economie politique, Ecole des Hautes Etudes en Sciences Sociales (EHESS), Paris, France, \\ ${ }^{6}$ Department of French language and literature, Seoul Women's University, Seoul, ROK, \\ ${ }^{7}$ Department of Companion animal and animal resources science, Joongbu University, Kumsan, ROK \\ *Corresponding Author \\ Sangdeog Augustin Kim
}

\section{Article History}

Received: 21.10 .2019

Accepted: 30.10 .2019

Published: 06.11.2019

\begin{abstract}
The present researchers undertook the continuous translation of Chinese characters through Korean pronunciation. The researchers have randomly chosen the Chinese characters, and counted the number of letters from 0041 to 0050 . The researchers deliberately separated the Chinese character into several parts. And the researchers combined the Korean pronunciation of those separated parts of the letter, and then investigate when assembled together if there is some meaning on a Korean pronunciation method. There is a difference between the original meaning and the present meaning, for example, "Open the door, please! My dear friend!" on the original meaning, while 'The morning' on the present meaning.

Keywords: Translation of Chinese characters, Korean pronunciation, letters from 0041 to 0050 , deliberate separation of the Chinese character into several parts, difference between the original meaning and the present meaning.
\end{abstract}

\section{INTRODUCTION}

The outstanding feature of the late Shang finds at An-yang is the writing they contain; not only is it unmistakably the Chinese language but it is also an early form of the Chinese writing system that still dominates East Asian civilization [1]. Here, Shang is the second country of the old China, and An-yang is the territory of the country. Dallet [2] found some of significant differences between the culture of China and that of Korea. For example the language and the origin of Korea is different from those of China. Park et al. [3] suggested Korean words were contained in Tcheonzamun(The thousand character essay) poem. And Park et al. [4] assumed that they could translate Chinese characters through the pronunciation of Korean words. So the present researchers undertook the continuous translation of other Chinese characters through Korean pronunciation.

\section{Materials ANd Methods}

The present researchers randomly chose the Chinese characters, and counted the number of letters from 0041 to 0050 . The researchers deliberately separated the Chinese character into several parts. And the researchers combined the Korean pronunciation of those separated parts of the letter. Then, the researchers were going to selecte an or two appropriate and possible combination(s) of the several parts of the letter. It is the object in order to catch the original meaning of the Chinese character.

\section{RESULTS AND DISCUSSION}

The researchers have tried to pronounce the part of the letter, and then investigate when assembled together if there is some meaning of the part of the letter on a Korean pronunciation method.

Copyright @ 2019: This is an open-access article distributed under the terms of the Creative Commons Attribution license which permits unrestricted use, distribution, and reproduction in any medium for non commercial use (NonCommercial, or CC-BY-NC) provided the original author and source are credited. 
0041 Keum(金):

1) Salzzag Kan; (人) (小) (干).

"The condition was bad (干; Kan) for somebody enough to do something extra-ordinary (人; Sal) (小; zzag). (the original meaning). 'The metal or the gold.' (the present meaning).

2) Sabang Bul Beolil; (人) (干) ( ) (ノ) (一).

"The metal seems to be the fire ( \; Bul) extended ( ; Beol) (一; il) in all the directions (人; Sa) (干; bang)!" (the original meaning). 'The metal or the gold.' (the present meaning).

$0042 \mathrm{Nam}$ (男):

1) Bat Him; (田) (力) $\Rightarrow$ Batchim.

"It is the support (田; Bat) (力; Him)!" (the original meaning).

'The man' (the present meaning).

2) Hanaga Yeol Him; (一) (山) (十) (力).

'Somebody has tremendously favorable affects to me. Even though he(she) is(山; ga) only one(一; Hana), he(she) has ten-fold(十; Yeol) power(力; Him) for me.' (the original meaning).

'The man.' (the present meaning).

0043 Yeo Nam (女男):

Neo Hanaga Yeol Him; (女) (一) (山) (十) (力).

'You(女; Neo) have great effect to me, you are(山; ga) only one(一; Hana), but you are for me more than 10 folds(十; Yeol) (力; Him) than other person is, you are truly valuable for me! Therefore rest with me, please!' (The original meaning).

'A man and a woman.' (The present meaning).

0044 Bak(朴):

Ma Zeo; $($ 木) $($ 卜 $\Rightarrow$ Mazeo!

"You are not wrong! You are right!(木; Ma) (ト; zeo !)" (the original meaning).

'simple.' (the present meaning).

0045 Bae(拜):

Byeo Igeo Dugeun Dugeun !; ( J ) (二) ( J ) (二) ( I ) (二) ( I !)

"We expect that the new rice( $)$; Byeo) will be harvested(二; I) ( J ; geo) soon, so we are really joy(二; Du) ( I ; geun) and happy ! ( 二; Du) ( I ; geun !)" (the original meaning).

'To bow.' (the present meaning).

$0046 \mathrm{Hwal}($ 活):

1) Bumbyeo Bumbyeo Hasigo !; ( 】 ) ( J )( \) ( J) (一) ( I ) (口 !)

"It is good (一; Ha) ( I ; si) (口; go) that the place is crowded with a lot of people !( \; Bum) ( $\mathrm{J}$; byeo) ( \; Bum) ( ; byeo !)" (The original meaning).

'It is alive.' (The present meaning).

2) Bumbyeo Bumbyeo Hasigo !; ( 】 ) ( J )( 】 ) ( ノ) (一) ( I ) (口 !)

"My family is blessed by the grace of Our Lord ( - ; Ha) ( I ; si) (口; go) with a lot of people !( \ ; Bum) ( J ; byeo) ( \; Bum) ( $\mathrm{J}$; byeo!)" (the original meaning).

'It is alive.' (The present meaning). 
$0047 \mathrm{Zo}$ (朝):

1) Zeobeog Zeobeog; (十) (日) (十) (月)

'It is a kind of sound when somebody walks(十; Zeo) (日; beog) (十; Zeo) (月; beog).' (the original meaning).

'The morning.' (The present meaning).

2) Yeoboge Yeoleo !; (十) (ト) (ヨ) (十) (月)

"Open the door, please ! (十; Yeol) (月; eo !) My dear friend ! (十; Yeo) (ト; bo) (크; ge !) " (the original meaning).

'The morning.' (the present meaning).

0048 Yeon(然):

Olggeoya ?; (月) (犬) (‥”)

"Are you coming here ? (月; OI) (犬; ggeo) ( $\cdots$; ya ?) " (the original meaning).

'It is natural." (The present meaning).

0049 Lo(路)

1) Zogak; (足) (各)

"This is a part(足; Zo) (各; gak) of land." (the original meaning).

'It is the road.' (the present meaning).

2) Bal Bbitchimi Yeogi; (足) ( J ) (一) (义) (口)

"Look on the bright side! Because we are fortunate to be able to come(足; Bal) ( ノ ; Bbitchim) (一; i) here ! (X; Yeo) (口; gi !)" (the original meaning).

'This is a road.' (the present meaning).

$0050 \mathrm{No}$ (奴)

1) Yeozaga Ddo !; (女) (又)

"If you have another woman (又; Ddo !) with your wife(女; Yeozaga), it is not good!" (the original meaning). 'He (she) is a slave.' (The present meaning).

2) Neo Ddong Na Byeol !; (女) (】) (一) ( ノ)

"I(一; Na) am an excellent person like star( ; Byeol!) in the heaven, but you(女; Neo) are a miserable one like feces( \; Ddong) in a toilette !" (the original meaning).

'The slave.' (the present meaning).

As a conclusion, there is a difference between the original meaning and the present meaning, for example, "Open the door, please! My dear friend!" on the original meaning, while 'The morning' on the present meaning.

\section{ACKNOWLEDGEMENTS}

We thank Mr Ilsoo Joseph Kim and Mrs Bohwa Kim, Mr Yeonghag Park and Mrs Hilye Sarah Kim, Ms Jieun Agatha Kim. We thank Father Jean Blanc and Father Hifumi Iwazaki. We thank Father GwangGeun Francesco Nam, Mrs Tamako Hayashi and Mr Yoshihiro Hayashi, Professor Francine Tenaillon and Professor Nicolas Tenaillon. We thank the students of Department of Companion Animal and Animal Resources Science in Joongbu University and the members of Daejeon Ludovich of Ordo Franciscanus Saecularis(OFS).

\section{References}

1. Fairbank, J.K., \& Reischauer, E.O. (1978). China -Tradition and transformation. Houghton Mifflin Company. USA, 17-65.

2. Dallet, C.H. (1874). Histoire de l'Eglise de Coree (History of Korean Catholic Church). Victor Palme. Paris. France, 11-99.

3. Park, H.R., Kim, J.A.(1), Kim, K.D.A., Kim, J.A(2)., Kim, S.T., Kim, R., Hamon, A., Tenaillon, N., Kim, S.A.(2017). Ancient Koreans petition to God in Tcheonzamun: The thousand character essay poem (641st to 656th letters). J. Lang. Cult, 8(6): 79-84.

4. Park, H.R., Kim, K.D.A., Kim, J.A., Kim, S.T., Kim, R., Hamon, A., Kim, S.A. (2019). The Story of Chinese Characters (00110020) When Translated On Korean Pronunciation. South Asian Res J Human Soc Sci, 1(3), 209-211. 